\title{
Malaysian Society of Neurosciences (MSN) - Asian and Oceanian Myology Centre (AOMC) Annual Scientific Meeting 2018
}

Kheng-Seang Lim ${ }^{1, *}$, Khean-Jin Goh ${ }^{1}$, Ai-Huey Tan ${ }^{1}$, Mustapha Muzaimi², Soon-Chai Low ${ }^{1}$

\footnotetext{
${ }^{1}$ Neurology Unit, Department of Medicine, Faculty of Medicine, University of Malaya, Kuala Lumpur, Malaysia.

${ }^{2}$ Department of Neurosciences, School of Medical Sciences, Health Campus, Universiti Sains Malaysia, Kubang Kerian, Kelantan, Malaysia.
}

* Correspondence: kslimum@gmail.com; Tel.: +603-79492585

Received: 13 December 2018; Accepted: 16 December 2018; Published: 20 December 2018

Edited and Reviewed by: King-Hwa Ling (Universiti Putra Malaysia); Norshariza Nordin (Universiti Putra Malaysia) https://doi.org/10.31117/neuroscirn.v1i2.23

\begin{abstract}
ABTRACT: The conjoint $17^{\text {th }}$ Asian and Oceanian Myology Centre (AOMC) and $28^{\text {th }}$ Malaysian Society of Neurosciences (MSN) Annual Scientific Meeting, held in Hotel Istana, Kuala Lumpur, Malaysia from 27 to 29 July 2018, was a great success to gather all neurosciences professionals locally and in the Asian-Oceanian region to share the latest updates in Neurology and specifically Myology. This congress attracted 516 local participants and 167 international delegates from 14 countries.
\end{abstract}

Keywords: myology; neurology; conference; Malaysia;

C2018 by Lim et al for use and distribution in accord with the Creative Commons Attribution (CC BY-NC 4.0) license (https://creativecommons.org/licenses/by-nc/4.0/), which permits unrestricted non-commercial use, distribution, and reproduction in any medium, provided the original author and source are credited.

\section{BACKGROUND OF MSN}

MSN was formed in 1987, by a group of neurologists and neurosurgeons, which subsequently expanded to include neuroscientists and other clinicians/health professionals involved in the care of neurology patients. This umbrella body for the neurosciences in Malaysia is part of the member societies of the World Federation of Neurology (WFN) and the International Brain Research Organization (IBRO). MSN provides a platform for professional exchange, education and collaboration amongst its members, with the aim to promote advancement of neuroscience in the country.
MSN also consists of various subspecialty chapters/councils including basic neuroscience, child neurology \& developmental pediatrics, stroke, epilepsy, movement disorder, clinical neurophysiology \& neuromuscular, and neuroimmunology \& neuroinfection.

With the increasing interest in neurosciences and the rapid development of this field in Malaysia and worldwide, MSN membership has been growing over the years, with over 700 members to date. We hope to attract new members in a continuous wave that seeks 
to inject eternal enthusiasm and bring about constructive and meaningful development of this very special branch of science. By working together, we will strengthen existing relationships, while building new networks both at local and international arenas.

MSN organizes an annual scientific meeting to promote neurology updates and education among the profession including junior doctors who are interested in neurology. It is also a platform for clinicians and researchers to share their research work and important clinical findings. We focus on one or more specific themes each year and occasionally organizes conjoint meetings with international or regional bodies within the country.

\section{FUTURE DEVELOPMENT OF NEUROSCIENCES IN}

\section{MALAYSIA}

There are approximately 102 neurologists, 115 neurosurgeons, 22 pediatric neurologists and 40 neuroscientists in Malaysia, serving more than 30 million population in Malaysia [1]. The ratio is significantly lower than our neighboring countries including Singapore, Thailand and Indonesia. MSN plays an important role in educating the general medical profession to identify and manage neurological cases and training the junior clinicians and neurology trainees according to the international standard of neurology practice. In addition, MSN has been and will continue to be a bridge to inform and update the local community regarding the latest findings in neurosciences, as well as ensuring the quality of current practices based on latest evidences. In addition, MSN provides a platform for clinicians for all neurosciences related disciplines and the neuroscientists to share resources and communicate. With the formation of subspecialty chapters and councils within the MSN, the society also plays a pivotal role in developing and promoting various important neurology subspecialty skills, services and interests in the country. Though it is a non-government organization, MSN is formed by the experts and leaders in the field of neurosciences, and will definitely play a significant role in the development of neurosciences and neurological care in Malaysia.

\section{BACKGROUND OF AOMC}

The Asian and Oceanian Myology Center (AOMC) was inaugurated and had its first annual scientific meeting in Tokyo, Japan in January 2001. The AOMC executive board members represent countries in the Asia and Oceanian region. Its aims are to: -

- promote basic and clinical scientific research in the neuromuscular field, with an aim to maintain provision of excellent evidence-based patient care

- provide a scientific forum where members can be updated on the advances and innovations in the neuromuscular field.

- provide educational opportunities for young investigators and clinicians.

- promote the achievement of standards in clinical practice in neuromuscular field and allied medical services in the Asian and Oceanian region.

- encourage new and strengthen existing multidisciplinary collaborations.

The $17^{\text {th }}$ Annual Scientific Meeting of the AOMC in 2018 was held in Kuala Lumpur in conjunction with the $28^{\text {th }}$ MSN annual scientific meeting. Figure 1 and Figure 2 depict the organizing chairs and committee members of the event, respectively.

\section{MSN-AOMC 2018: EMINENT DELEGATES IN THE FIELD OF MYOLOGY}

The main themes for MSN-AOMC meeting were Inflammatory Myopathies and Translational Research in neuromuscular diseases. The meeting was attended by international experts including Professor Werner Stenzel (neuropathologist from Charite Hospital, University of Medicine, Berlin) who spoke on inflammatory myopathy, Professor Giampetro Schiavo (cellular neurobiologist, University College London (UCL)) whose talks were on axonal transport and the central effects of botulinum toxins and $\mathrm{Dr}$ Rahul Phadke (neuropathologist, UCL, Queens Square) who 


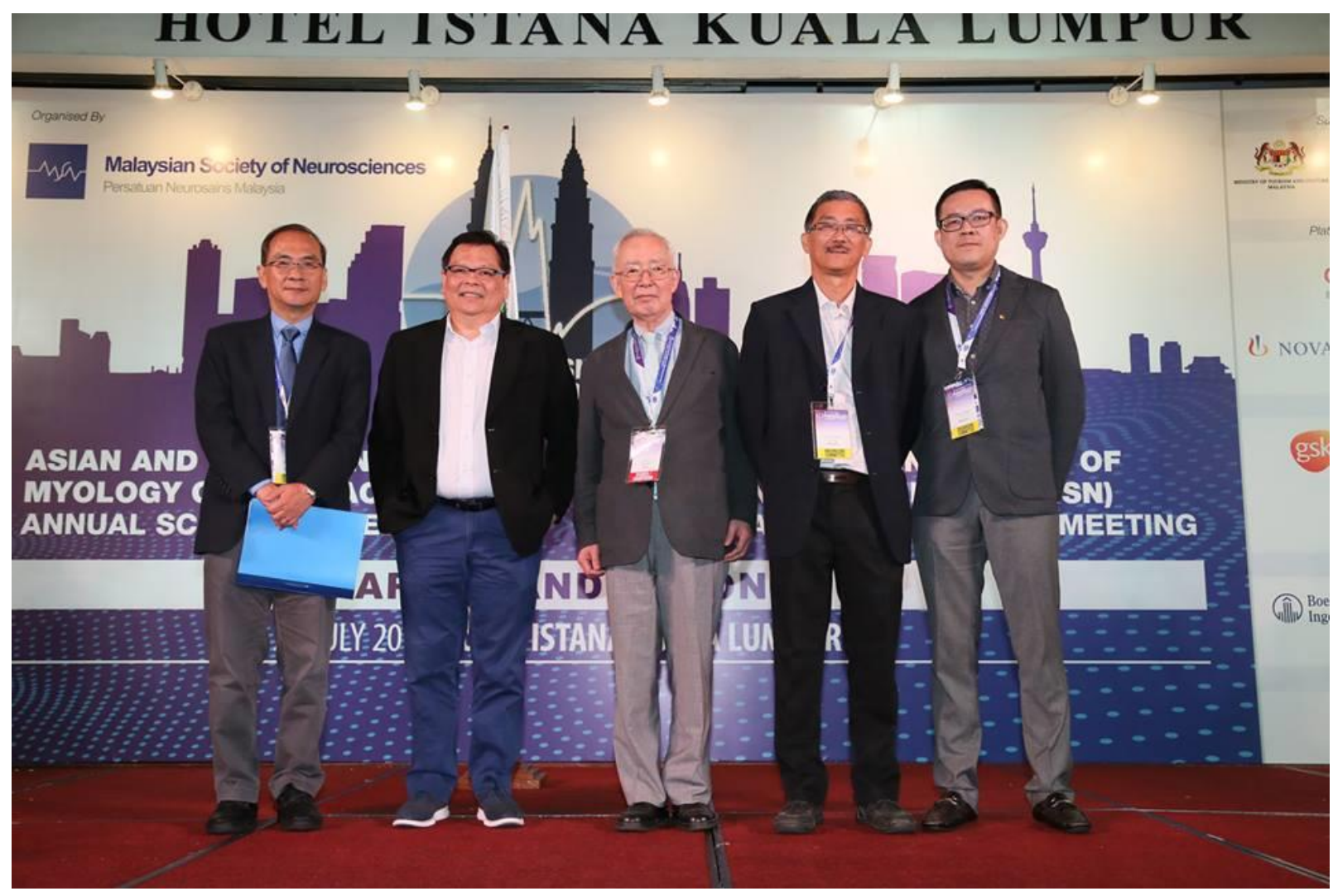

Figure 1. MSN-AOMC Organizing Chairs and AOMC President. (From left to right) Khean-Jin Goh, Raymond Rosales, Ikuya Nonaka, Kum-Thong Wong, Kheng-Seang Lim.

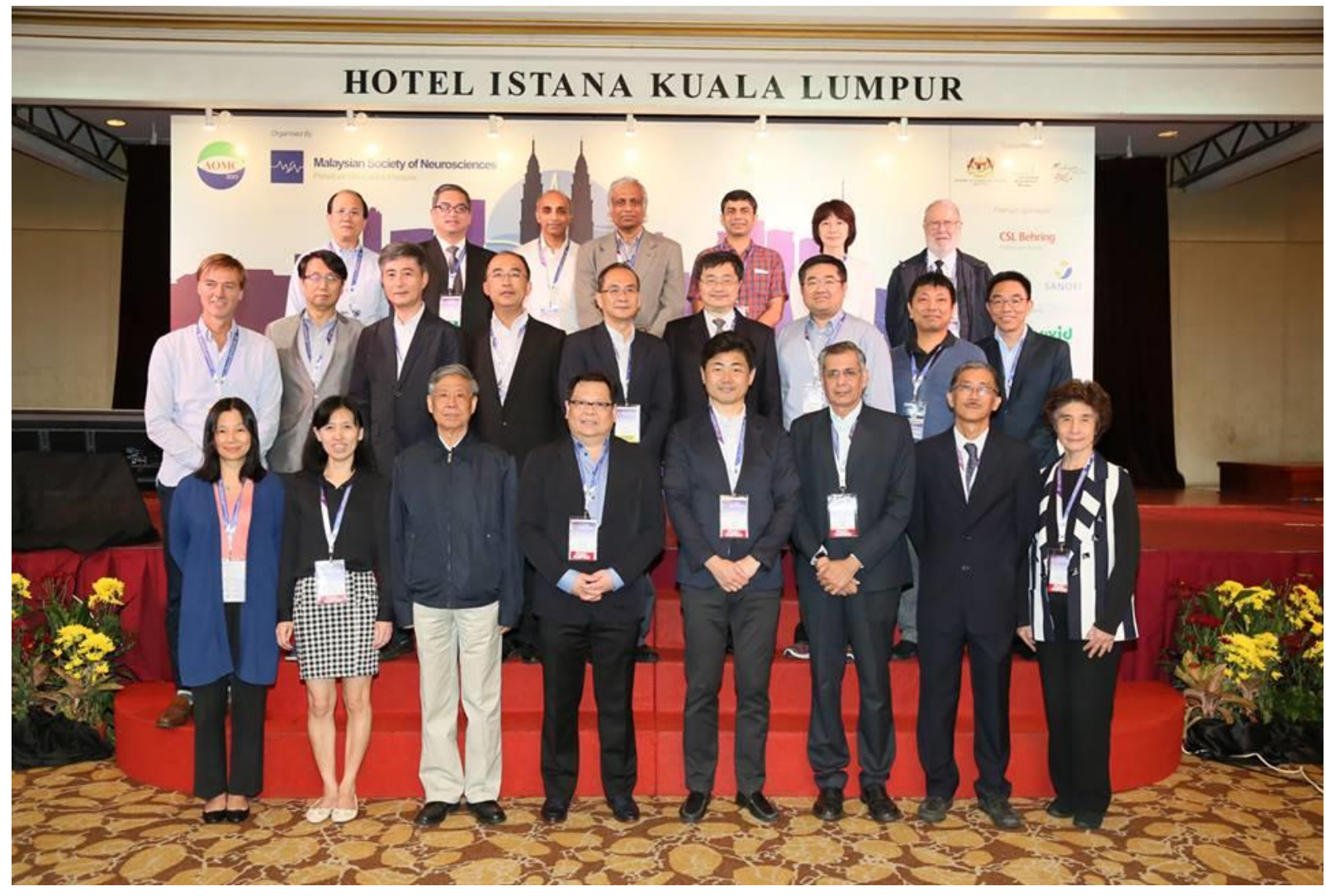

Figure 2. AOMC committee members, faculties and national delegates. 
discussed the role of neuropathology in the era of Next Generation Sequencing (NGS). In addition, we have two well-known neuromuscular experts, Professor Alberto Dubrovsky (Argentina) and $\mathrm{Dr}$ Andoni Urtizberea (France) speaking in the congress teaching course. All invited international speakers of event are illustrated in Figure 3. The MSN-AOMC 2018 conjoint meeting was well attended by delegates from China, Taiwan, Hong Kong, India, Indonesia, Japan, Myanmar, Pakistan, Philippines, Singapore, South Korea, Thailand, United States and Vietnam.

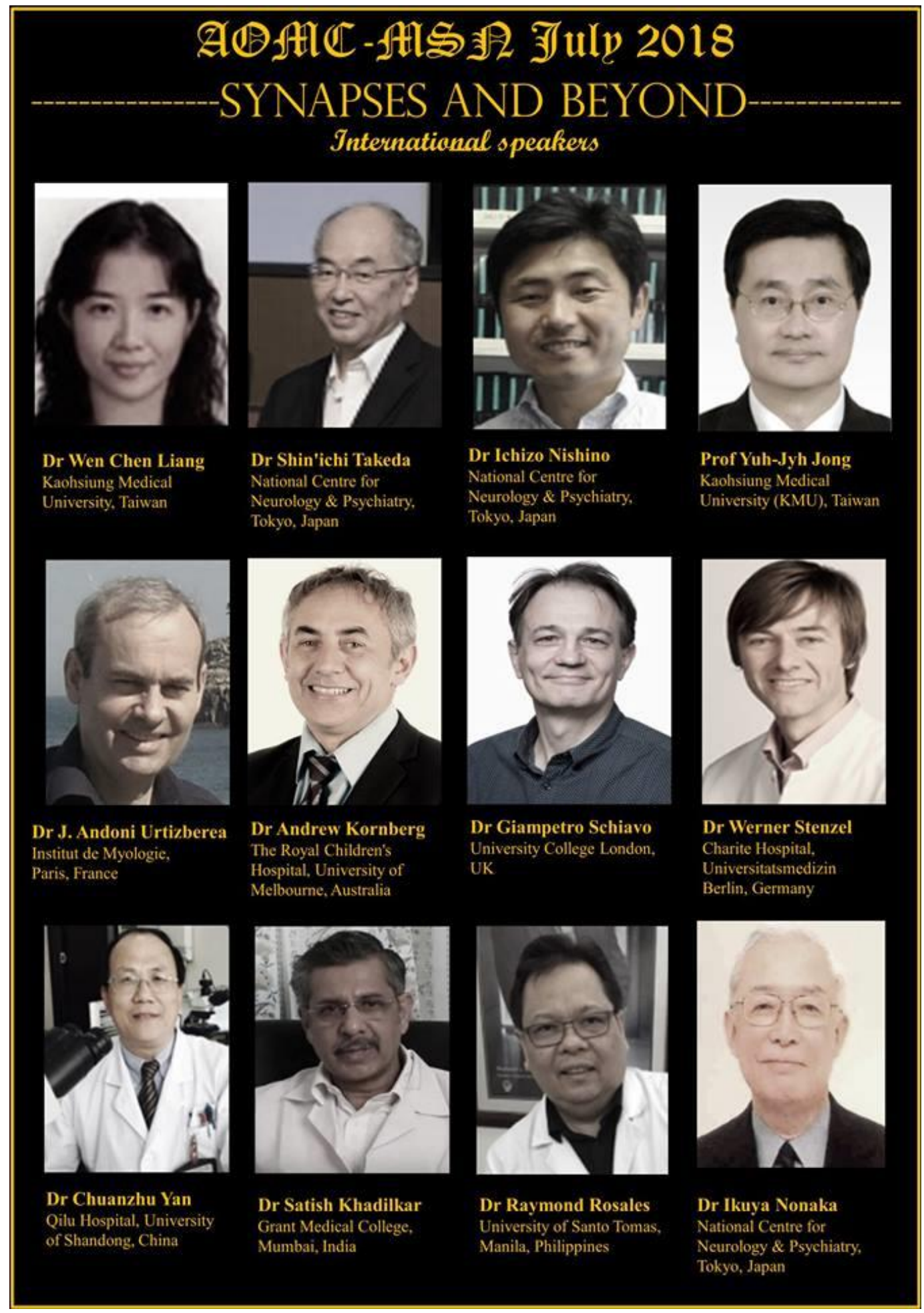

Figure 3. Invited international speakers of MSN-AOMC 2018. 


\section{AWARDS AND AWARDEES}

Five outstanding attendees were awarded AOMC Travel grant supported by the Ayaka Foundation, Japan (URL reference). The recipients were $\mathrm{Dr}$ Kiran Polavarapu and Dr Veeramani Preetish-Kumar (India), Dr Shuang Cai (China), Dr Yan Lynn Aung (Myanmar), Dr Luh Ari Indrawati (Indonesia) and Dr Si Tri Le (Vietnam). In addition, several cases were discussed in the Clinical-Pathological Case session and a total of 50 free papers were presented. One of the two awards for best free paper was presented to Kyowon Seo, DaeSeong Kim and Jin-Hong Shin from Pusan National University Yangsan Hospital, Yangsan, South Korea for their paper on "Dysferlinopathy was recovered by read through therapy through ataluren". The other award went to Lin Ge, Xiaona Fu, Wei Zhang, Dong Wang, Zhaoxia Wang, Yun Yuan, Ikuya Nonaka and Hui Xiong from Peking University First Hospital, China for their paper related to "A new titinopathy: recessive TTN variants cause a novel form of early-onset multi-mini core disease without cardiac involvement".

MSN offers two awards for young researchers below 40 years old, and two for best publications each year, in both clinical and non-clinical categories. These publication awards aim to cultivate the research culture in the country especially amongst the young researchers in the field of neurosciences. During the MSN annual scientific meeting, we also set up a platform for oral and poster presentations in neurosciences related topics. Besides learning updates from world-renowned experts in the field, the local clinicians and scientists can contribute to the knowledge of neurosciences via this platform. Table 1 summarizes the awardees for MSN-AOMC 2018.

Table 1: List of MSN-AOMC 2018 awards and recipients.

\begin{tabular}{|c|c|c|}
\hline \multicolumn{3}{|l|}{$\begin{array}{l}\text { Non-Clinical } \\
\text { Category }\end{array}$} \\
\hline Award category & Recipient(s) & Award descriptions \\
\hline $\begin{array}{l}\text { MSN Young } \\
\text { Investigator Award }\end{array}$ & $\begin{array}{l}\text { Dr Nareshwaran Gnanasegaran } \\
\text { (University of Malaya, Malaysia) }\end{array}$ & $\begin{array}{l}\text { For his publication entitled "Effect of dental pulp stem cells } \\
\text { in MPTP-induced old-aged mice model" published in } \\
\text { European Journal of Clinical Investigation with an impact } \\
\text { factor of } 2.71 \text {. }\end{array}$ \\
\hline $\begin{array}{l}\text { MSN Best } \\
\text { Publication Award }\end{array}$ & $\begin{array}{l}\text { Mr Uday Praful Kundap } \\
\text { (Monash University Malaysia, } \\
\text { Malaysia) }\end{array}$ & $\begin{array}{l}\text { For his publication entitled "Zebrafish as a model for } \\
\text { epilepsy-induced cognitive dysfunction: a pharmacological, } \\
\text { biochemical and behavioral approach" published in } \\
\text { Frontiers in Pharmacology with an impact factor of } 4.40 .\end{array}$ \\
\hline \multirow[t]{2}{*}{$\begin{array}{l}\text { Best Oral } \\
\text { Presentation } \\
\text { Awards }\end{array}$} & $\begin{array}{l}\text { First Prize } \\
\text { Nurul Iman Wan Ismail (Universiti } \\
\text { Sains Malaysia) }\end{array}$ & $\begin{array}{l}\text { "Mitragynine (Ketum) induced memory impairment of Swiss } \\
\text { albino mice in the IntelliCage }{ }^{\circledR} \text { system" }\end{array}$ \\
\hline & $\begin{array}{l}\text { First Runner Up } \\
\text { Nurul Aqmar Mohamad Nor Hazalin } \\
\text { (Universiti Sains Malaysia) }\end{array}$ & $\begin{array}{l}\text { "Anti TRPM4 antibody improves hippocampal long-term } \\
\text { potentiation deficit in chronic cerebral hypoperfused Rats" }\end{array}$ \\
\hline \multirow[t]{2}{*}{ Best Poster Awards } & $\begin{array}{l}\text { First Prize } \\
\text { Che Mohd Nasril Che Mohd Nassir } \\
\text { (Universiti Sains Malaysia) }\end{array}$ & $\begin{array}{l}\text { "Cerebral small vessel disease (CVSD) in apparently } \\
\text { asymptomatic individuals: mutimodalities logitudinal study" }\end{array}$ \\
\hline & $\begin{array}{l}\text { First Runner Up } \\
\text { Mazira Mohamad Ghazali (Universiti } \\
\text { Sains Malaysia) }\end{array}$ & $\begin{array}{l}\text { "Correlations between ischaemic cerebral white matter } \\
\text { changes and the neurocognitive profiles in apparently } \\
\text { asymptomatic individuals" }\end{array}$ \\
\hline \multicolumn{3}{|l|}{ Clinical Category } \\
\hline Award category & Recipient(s) & Award descriptions \\
\hline $\begin{array}{l}\text { MSN Young } \\
\text { Investigator Award }\end{array}$ & $\begin{array}{l}\text { Dr Hwong Wen Yea } \\
\text { (National Clinical Research Centre, } \\
\text { Ministry of Health Malaysia) }\end{array}$ & $\begin{array}{l}\text { For her publication entitled "Prescription of secondary } \\
\text { preventive drugs after ischemic stroke: results from the } \\
\text { Malaysian National Stroke Registry" published in BMC } \\
\text { Neurology with an impact factor of } 2.00 \text {. }\end{array}$ \\
\hline
\end{tabular}




\begin{tabular}{|c|c|c|}
\hline $\begin{array}{l}\text { MSN Best } \\
\text { Publication Award }\end{array}$ & $\begin{array}{l}\text { Dr Tan Ai Huey } \\
\text { (University of Malaya, Malaysia) }\end{array}$ & $\begin{array}{l}\text { For her publication entitled "Altered gut microbiome and } \\
\text { metabolome in patients with multiple system atrophy" } \\
\text { published in Movement Disorders with an impact factor of } \\
7.07 \text {. }\end{array}$ \\
\hline \multirow[t]{2}{*}{$\begin{array}{l}\text { Best Oral } \\
\text { Presentation } \\
\text { Awards }\end{array}$} & $\begin{array}{l}\text { First Prize } \\
\text { Dr Chong Kah Kian } \\
\text { (University Malaya Medical Centre, } \\
\text { Malaysia) }\end{array}$ & $\begin{array}{l}\text { "A randomized double-blind placebo-controlled trial of } \\
\text { probiotics for constipation in Parkinson's disease" }\end{array}$ \\
\hline & $\begin{array}{l}\text { First Runner Up } \\
\text { Dr Hor Chee Peng } \\
\text { (Hospital Kepala Batas/ CRC Seberang } \\
\text { Jaya, Malaysia) }\end{array}$ & $\begin{array}{l}\text { "Impact of pre-stroke angiotensin converting enzyme } \\
\text { inhibitors (ACEi) on pneumonia during acute stroke: an } \\
\text { Asian perspective" }\end{array}$ \\
\hline \multirow[t]{2}{*}{ Best Poster Awards } & $\begin{array}{l}\text { First Prize } \\
\text { Dr Schee Jie Ping } \\
\text { (Hospital Kuala Lumpur, Malaysia) }\end{array}$ & "Overlap syndrome in demyelinating diseases" \\
\hline & $\begin{array}{l}\text { First Runner Up } \\
\text { Dr Sheila Ong Ai Mei } \\
\text { (Hospital Kuala Lumpur, Malaysia) }\end{array}$ & $\begin{array}{l}\text { "Longitudinally extensive transverse myelitis (LETM) } \\
\text { mimickers of neuromyelitis optica spectrum disorders } \\
\text { (NMOSD): clues to diagnostic recognition" }\end{array}$ \\
\hline
\end{tabular}

\section{CURRENT MSN EXECUTIVE COMMITTEE (SESSION} 2018-2020)

A new team of energetic MSN executive committee (EXCO) is elected every two years. During MSN-AOMC 2018, the following EXCO members were elected during the $29^{\text {th }}$ MSN Annual General Meeting. The new EXCO is determined to steer the society to a higher ground with greater and significant development and research as well as educational activities during their term.

\section{President}

Dr Tan Ai Huey (University Malaya Medical Center)

\section{Vice President}

Dr Shanthi Viswanathan

(Kuala Lumpur General Hospital)

\section{Vice President}

Associate Professor Dr. Muzaimi Mustapha

(Universiti Sains Malaysia)

\section{Honorary Secretary}

Dr Tan Kenny (Penang General Hospital)

\section{Honorary Treasurer}

Dr Anwar Norazit (University of Malaya)

\section{Assistant Treasurer}

Dr Siti Rafidah bt Yusof (Universiti Sains Malaysia)

\section{Committee Members}

Dr Law Wan Chung

(Sarawak General Hospital)

Associate Professor Dr Rabani Remli

(Universiti Kebangsaan Malaysia Medical Center)

Dr Khairul Azmi Ibrahim

(Hospital Sultanah Nur Zahirah)

Associate Professor Dr Fong Choong Yi

(University Malaya Medical Center)

Dr Goh Kwang Hwee (Regency Specialist Hospital)

\section{FUTURE EVENTS BY MSN}

MSN will be celebrating its $30^{\text {th }}$ anniversary in the upcoming annual scientific meeting in Kota Bahru, Kelantan, from 5-7 July 2019. The focus of the scientific program will be on neurology emergencies. Highlights of MSN 2019 include sharing of experiences by the senior consultants in the country, plenary sessions by international experts and the Mohandas Memorial Lecture. Further information is available at www.msn2019.org.

Author Contributions: All authors wrote and contributed to the content of the report.

Conflicts of Interest: The authors declare no conflict of interest.

\section{References}

1. National Specialist Register. Available online: https://www.nsr.org.my/index2.htm (Accessed 12 December 2018) 